Dmytro V. Stefanyshyn ${ }^{1}$, D. S. (Engineering), Senior Research Scientist

ORCID ID: 0000-0002-7620-1613 e-mail: d.v.stefanyshyn@gmail.com

Yaroslaw V. Khodnevich ${ }^{1}$, PhD (Engineering), Research Scientist

ORCID ID: 0000-0002-5510-1154 e-mail: ya.v.khodnevych@gmail.com

Vasyl M. Korbutiak ${ }^{2}$, PhD (Engineering), Associated Prof. of Department

ORCID ID: 0000-0002-8273-2306 e-mail:v.m.korbutiak@nuwm.edu.ua

${ }^{1}$ Institute of Telecommunications and Global Information Space of NASU, Kyiv, Ukraine

${ }^{2}$ National University of Water and Environmental Engineering, Rivne, Ukraine

\title{
ESTIMATING THE CHÉZY ROUGHNESS COEFFICIENT AS A CHARACTERISTIC OF HYDRAULIC RESISTANCE TO FLOW IN RIVER CHANNELS: A GENERAL OVERVIEW, EXISTING CHALLENGES, AND WAYS OF THEIR OVERCOMING
}

\begin{abstract}
This paper deals with results of a systemized overview of the Chézy roughness coefficient calculation problem as one most frequently used empirical characteristics of hydraulic resistance. The overview is given in the context of the formation of reliable empirical data needed to support hydro-engineering calculations and mathematical modelling of open flows in river channels. The problem topicality is because of a large number of practical tasks which need such a pre-research. In many cases, the accuracy of determining empirical hydraulic resistance characteristics can largely affect the accuracy of solving tasks relating to designing hydraulic structures and water management regardless of chosen mathematical models and methods.

Rivers are characterized by a significant variety of flow conditions; hydraulic resistance to flows in rivers can thus vary widely determining their flow capacity. Considering the variety of river hydro-morphology and hydrology, the Chézy roughness coefficient often appears to be the most complete characteristic of hydraulic resistance to open flows in river channels comparing with other integral empirical characteristics of hydraulic resistance.

At present, there are a large number of empirical and semi-empirical formulas to calculate the Chézy roughness coefficient. The main aim of this study was to analyze and systematize them in the context of providing proper support to the open channel hydraulics tasks. To achieve the aim of the study, a literature review regarding the problem of determining the integral hydraulic resistance characteristics to open flow in river channels was performed, as well as formulas used to calculate the Chézy roughness coefficient in practice were explored and systemized. In total, 43 formulas to calculate the Chézy roughness coefficient, as well as 13 formulas that can be used to estimate the Manning roughness coefficient were analyzed and systematized. Based on all these formulas, about 250 empirical equations can be compiled to calculate the Chézy coefficient depending on hydro-morphological peculiarities of rivers and river channels, hydraulic conditions, formulas application limits, and so on.
\end{abstract}

Keywords: empirical characteristics; hydraulic resistance; open flows; open channel hydraulics; river channels; Chézy roughness coefficient

DOI: https://doi.org/10.32347/2411-4049.2021.3.16-43

(C) D.V. Stefanyshyn, Ya.V. Khodnevich, V.M. Korbutiak, 2021

ISSN: 2411-4049. Екологічна безпека та природокористування, № 3 (39), 2021 


\section{Introduction}

Rivers, riverine valleys, and riparian territories have traditionally been considered by humans as an important resource environment, despite essential threats connected with natural river waters [1]. Rivers are still the main source of drinking, industrial and agrarian water supply in the world, serve as reliable transport routes [2], and provide hydropower development [3]. They are extremely attractive places for urbanization and mass settlement of people. It is thus utterly irrational not to use the river environment in economics and vital activities. Moreover, rivers are among the crucial natural ecosystems, both local ones and of the world [4], and also are important for the recreation and tourism industry $[5,6]$. Currently, more than one billion people in the world live in areas adjacent to rivers [7].

There are a lot of hydro-engineering tasks relating to open flow in river channels. Foremost, these are traditional hydraulic calculations of the river channels' capacity and the position of the free water surface, which are essential ones for designing hydraulic structures [8-10]. There are also the special tasks of mathematical modelling to determine the parameters of flood wave propagation and water releases from reservoirs including dam-break flood waves [11-14], as well as prediction of general and local riverbed erosion [4, 15-18], alluvium transport and sedimentation [19-23], hydraulic modelling for designing highways [20], and other infrastructure within the river environment [17, 22, 23]. It should also be mentioned tasks for providing integrated approaches to water resources management in river basins [24] including flood control measures [25, 26], riverine ecosystem management, and river revitalization work [4, 27], and so on.

The investigation and modelling of open flows in river channels is a complex problem. When solving it, independently on the research topic and methods used, a number of simplifications and assumptions are usually accepted. There are also a number of parametric uncertainties requiring an empirical pre-research to overcome them. First of all, they relate to establishing hydraulic resistances, which can vary significantly in time and space depending on many factors [8-10].

Hydraulic resistance is the force with which the bed, banks of a river including its floodplain interferes with the movement of water flow. The key factors affecting hydraulic resistance in river channels are the following: elements of roughness including bottom ridges and riffles, turns and bends of the channel, heterogeneity of size and shape of the channel along the length, suspended and bottom sediments, vegetation, ice and others. Due to the variety of water flow conditions in river channels, their hydraulic resistance can vary widely determining their flow capacity, water flow velocities and discharges, water levels and flooding.

When expressing the hydraulic resistance, the following integral empirical characteristics are usually used: the Chézy roughness coefficient $C\left(\mathrm{~m}^{1 / 2} / \mathrm{s}\right)$, the Manning (Gauckler - Manning) roughness coefficient $n\left(\mathrm{~s} / \mathrm{m}^{1 / 3}\right)$, and the Darcy Weisbach friction factor $\lambda$. There are three well-known empirical equations linking mean flow velocity $V$ to the hydraulic resistance expressed by these characteristics. They are the Chézy, Manning (Gauckler - Manning or Gauckler - Manning Strickler), Darcy - Weisbach equations, accordingly [8-10]:

$$
V=C \sqrt{R \cdot S_{f}},
$$




$$
\begin{gathered}
\sim 18 \sim \\
V=\frac{1}{n} R^{\frac{2}{3}} \sqrt{S_{f}}, \\
V=\sqrt{\frac{8 g \cdot R \cdot S_{f}}{\lambda}},
\end{gathered}
$$

where $V=Q / A$ is the depth-averaged or cross-sectional averaged velocity $(\mathrm{m} / \mathrm{s})$, $Q$ is the water discharge $\left(\mathrm{m}^{3} / \mathrm{s}\right), A=B \cdot h$ is the cross-sectional area of the flow $\left(\mathrm{m}^{2}\right), B$ is the average flow width $(\mathrm{m}), h$ is the average flow depth $(\mathrm{m}), R=A / P$ is the hydraulic radius (m), $P$ is the wetted perimeter $(\mathrm{m}), S_{f}$ is the energy grade line slope (or the water surface slope); $g$ is the gravitational acceleration $\left(\mathrm{m} / \mathrm{s}^{2}\right)$.

Usually, the Chézy roughness coefficient $C$ and the Manning roughness coefficient $n$ are used in calculating the averaged velocity of open flows; the Darcy Weisbach friction factor $\lambda$ is used for calculating the averaged velocity water movement in pipelines [8-10]. However, the Darcy - Weisbach formulation of flow resistance may be used for open channels as well [21, 34].

Let the Chézy, Manning, and Darcy - Weisbach equations (1)-(3) be summarized as [23, 28-33]:

$$
V=C \sqrt{R \cdot S_{f}}=\frac{1}{n} R^{\frac{2}{3}} \sqrt{S_{f}}=\sqrt{\frac{8 g \cdot R \cdot S_{f}}{\lambda}} .
$$

Then the following simple formal relationships between the roughness coefficients $C, n$, and the friction factor $\lambda$ are established: the Chézy coefficient $C$ may relate to the Darcy - Weisbach friction factor $\lambda$ as $[9,10]$ :

$$
C=\sqrt{\frac{8 g}{\lambda}} \text { or } \lambda=\frac{8 g}{C^{2}},
$$

the Darcy - Weisbach friction factor $\lambda$ may relate to the Gauckler - Manning roughness coefficient $n$ as $[34,35]$ :

$$
\lambda=\frac{8 g \cdot n^{2}}{R^{1 / 3}} \text { or } n=\sqrt{\frac{\lambda \cdot R^{1 / 3}}{8 g}},
$$

and, in turn, the Chézy roughness coefficient $C$ may relate to the Manning (Gauckler - Manning) roughness coefficient $n$ as:

$$
C=\frac{1}{n} R^{1 / 6} \text { or } n=\frac{C}{R^{1 / 6}} .
$$

The equations (1)-(3) are considered to be valid for the quadratic region of resistances for the case of steady uniform flow in channels occurring when the depth $h$, flow area $A$, and velocity $V$ at every cross section are constant, and the energy 
grade line slope (or the water surface slope, hydraulic slope) $S_{f}$ is equal to the channel bed slope $S_{0}$, that is $S_{f}=S_{0}$. In general, uniform flow can occur only in very long, straight, and prismatic channels. Although the definition of uniform flow and the assumptions required to consider equations (1)-(3) are rarely satisfied in practice, the concept of uniform flow is central to the understanding and solution to many practical tasks of open-channel hydraulics [8-10].

Today, empirical characteristics of hydraulic resistance are used in numerous practical hydraulic and fluid mechanics tasks. In particular, they are used in the widespread one and two-dimensional flow models of shallow water (De Saint Venant equations in the French scientific community), which are successfully applied in mathematical modelling of flows with free surface [12, 21-23, 35, 36] including dam-break simulations [13, 14, 37, 38], torrential flows (or so-called flash floods) modelling [39, 40], sediment-laden flows modelling [21], debris flows simulation [33] and pollutant transport modelling [41], as well as the pyroclastic and granular masses movement modelling [42], and the simulation of large-scale atmospheric, sea and ocean currents [43] etc. They are used in the modern computational HEC-RAS River Analysis System supporting steady and unsteady flow water surface profile calculations, sediment transport computations, and water quality analyses etc. [44]. They are not used only in the Navier - Stokes equations of the real fluid motion and in Reynolds averaged equations of turbulent water flow, which describe the behaviour of an unsteady three-dimensional flow. However, results obtained from traditional hydraulic calculations and flow modelling due to shallow water models may be used as boundary conditions for computations with Reynolds and Navier - Stokes equations [17, 18, 27, 43-45].

\section{Problem statement, aim and objectives of the research}

Because of the huge variety of conditions of water flow in open channels of natural rivers, the characteristics of hydraulic resistance to flow can vary in space and time significantly. They can vary depending on natural riverbed conditions and seasonal hydraulic and hydro-morphological conditions and so on, as well as under the influence of stochastic or even unpredictable factors including human activity. For example, in some parts of a river, the essential local elevations of water levels may occur due to compressions of the river channel downstream due to temporary formations, such as ice gorges, rubbish of logging, alluvial deposits etc. [46]. Often, depending on changes in the hydraulic resistance to flow, the same water levels in a river may correspond to different water discharges and vice versa. This complicates the solution of the majority of practical hydro-engineering tasks. In many cases, the accuracy of determining empirical hydraulic resistance characteristics can largely affect the accuracy of solving hydro-engineering problems relating to mathematical modelling of open flow in river channels regardless of chosen mathematical models or methods.

Admittedly, the most general approach to determining the numerical values of hydraulic resistance characteristics, which we cannot directly gauge, is to determine them in the frame of a chosen mathematical flow model by solving an inverse hydraulic problem [47] taking into account gauged characteristics of flow (the water discharge, flow velocity, flow width and depth, wetted perimeter, water surface slope, river bed morphology etc.) in control flow cross sections. Such inverse tasks 
are also called parameter identification problems of mathematical models [48]. The numerical values of the hydraulic resistance characteristics determined in the frame of solution of inverse hydraulic problems can be further successfully used in solving various practical hydro-engineering tasks concerning the traditional and special hydraulic calculations.

However, the approach based on the solution of inverse problems has got not only important advantages promoting mathematical modelling but also a number of serious practical disadvantages. First of all, this approach may be applied only to rivers monitored by gauges or to well-gauging parts of rivers, which have a sufficient number of hydrological gauges to control actual flow characteristics (levels and discharges of water flow). As well as, there remains a need for large-scale field investigations of the river hydro-morphology taking into account spatial-temporal hydro-morphological changes occurring in the riverbed and floodplain for seasons, in particular, due to recent floods etc. In addition, the hydraulic resistance characteristics that have been identified in the frame of solving an inverse hydraulic problem may be adequately used only for the pre-chosen mathematical model, which was subject to parametric identification including its boundary and initial conditions. However, as practice shows [46], when resolving next predictive tasks, the boundary and initial conditions can vary significantly and unpredictably in time. They must be repeatedly adjusted using results of additional field research. Current remote sensing data make the task easier. However, this data is implicit. They also need to be identified [49, 50]. Eventually, for ungauged rivers, where hydrometric observations are not performed, the empirical approach using equations (1)-(3) still remains the only possible one.

For example, in the simplest case, when the average flow width $B>>h$ and thus $R \cong h$, to identify the Gauckler - Manning roughness coefficient $n$ according to results of hydrological and hydro-morphological observations for a selected area of a river the empirical Manning equation (model) (2) may be used. In this case, to solve the inverse problem of parametric identification it is needed that within this area we know the water discharge $Q$ or depth-averaged or cross-sectional averaged velocity $V$, average flow depth $h$ and average flow width $B$, as well as marks of the river channel bottom levels $z_{b}$ or water surface levels $z_{w}$.

Let $S_{f}=\Delta z / L, \Delta z=z_{u}-z_{d}$ be, where $z_{u}, z_{d}$ are marks of a river bottom or water levels in cross-sections of upstream and downstream of a selected area of the river channel of length $L$ along the flow. Then, according to Manning equation (2), the roughness coefficient $n$ may be estimated (identified) as:

$$
n=\frac{h^{2 / 3} \cdot \sqrt{\frac{z_{u}-z_{d}}{L}}}{V} .
$$

The relative simplicity of determining the roughness coefficient $n$ by solving the inverse problem for open-channel flows based on the use of the Manning equation (2) allowed developing summarized tables of its values depending on open channel types, qualitative description of channel morphology, and conditions of flow [8-10]. These tables have been widely used in practice. However, for different watercourses and cases described in these tables, the roughness coefficient values vary 
substantially including significant variations in some range (minimum, normal, maximum values) for each special case [8-10]. Therefore, the ultimate choice of a design value of the roughness coefficient value in each specific case depends essentially on a decision-making expert.

In turn, to identify the Gauckler - Manning roughness coefficient $n$ using Darcy Weisbach equation (3) and get the same result (8) we should consider not only the appropriate equation (3) but also the condition (6) linking formally the Darcy Weisbach friction factor $\lambda$ and the roughness coefficient $n$. The key issue here is that in a formal way the friction factor $\lambda$ may be determined much more accurately as a function of relative roughness and Reynolds number characterizing flow regime [51]; whereas, the roughness coefficient values obtained from (8) do not depend on Reynolds number and flow regime. Further, to identify the roughness coefficient $n$ using Chézy equation (1) and get the same result (8) we should consider not only the appropriate equation (1) but also the condition (7) linking the Chézy coefficient $C$ and the Gauckler - Manning coefficient $n$. Herewith, the Chézy coefficient $C$ may relate simultaneously to the Darcy - Weisbach friction factor $\lambda$ as (5). However, because equations (1)-(3) are empirical ones, actually, they cannot give the same results. Eventually, in a more general case, a more appropriate formula for identifying the roughness coefficient based on the Chézy equation (1) can be written as:

$$
n=\frac{h^{0,5+y} \cdot \sqrt{\frac{z_{u}-z_{d}}{L}}}{V},
$$

where $y$ is some degree indicator modelling the empirical relationship between the Chézy roughness coefficient $C$ and the Manning roughness coefficient $n$.

The formula (9) seems to be more complete to identify the Gauckler - Manning roughness coefficient $n$ than the formula (8) as it contains the indicator $y$, which can vary. This may also indicate that the Chézy equation (1) is a more universal and convenient empiric model to monitor the hydraulic resistance to open flow than Gauckler - Manning (2) and Darcy - Weisbach (3) equations. This is especially true of natural watercourses like rivers, which are characterized by a significant variety of flow conditions, and where it is quite problematic, for example, to determine the Darcy - Weisbach friction factor $\lambda$.

Today, there are a large number of empirical and semi-empirical formulas used to calculate the Chézy roughness coefficient $C$. The main aim of this study is to systematize these formulas in the context of providing a proper support for mathematical modelling of open flows in natural channels. To achieve the aim of the study, the following objectives were set: (1) to perform a literature review regarding the problem of estimating the integral hydraulic resistance characteristics to open flow in river channels; (2) to explore and systemize principal empirical and semiempirical formulas, which may be used to estimate the Chézy roughness coefficient as an integral characteristic of hydraulic resistance to open flow in river channels; (3) to detect existing challenges to computing the Chézy roughness coefficient, and propose ways of their overcoming. 


\section{Materials and methods}

As materials for the research we used well-known classical literature on open channel hydraulics [8-10], reference books, tutorials, and manuals [22, 44, 52-57], articles presenting the results of original research on calculating hydraulic resistance in open channels [28-34, 58-60], and, in particular, articles devoted to determining the Darcy - Weisbach friction factor [51, 61-64], the Gauckler - Manning roughness coefficient [52, 65-69], and the Chézy resistance coefficient [28, 70-73], as well as recent publications on mathematical modelling of uniform and non-uniform water flow in open channels [22, 23, 25, 27, 35-39, 41, 43, 45].

As methods, when researching, there were used: historical method, method of dialectical cognition and generally scientific methods of theoretical and empirical research, heuristic methods, methods of analysis and synthesis, methods of expert evaluation and comparison, methods of formalization and modelling, systemic approach to the investigation of factors and mechanisms their development. As a result of the study, a general classification and systematization of main empirical and semi-empirical formulas and dependencies to compute the Chézy resistance coefficient was proposed taking into account the conditions and features of their application in practice.

\section{Formulas used to calculate the Chézy resistance coefficient}

At present, there is a large number (more than 100) of different empirical and semiempirical formulas and dependencies by which the Chézy resistance coefficient can be calculated [8-10, 28, 29, 34, 52-59, 61, 70-73]. Many of them, for example, may be derived from the dependences linking the Chézy resistance coefficient with the roughness coefficient and the Darcy - Weisbach friction factor. The latter ones, in turn, can be also determined due to various empirical formulas [58, 59, 62, 64, 71]. Most of the examined formulas have limited application meeting specific flow conditions, or were derived from poor laboratory or natural material. However, among the wide variety of formulas to compute the Chézy resistance coefficient the most well-known and original dependencies and equations most used in practice have been revealed.

In general, all the existing empirical formulas and dependencies used to calculate the Chézy coefficient can be divided into four main groups.

The first group consists of formulas in which mostly there is established the dependence of the Chézy coefficient $C$ on the roughness coefficient $n$ characterizing the roughness of the banks and the bottom of a river channel. They also include, the hydraulic radius $R$ or the average flow depth $h$ provided that the average flow width $B>>h$ and $R \cong h$ :

$$
C=f(n, R), \text { or } C=f(n, h)
$$

The second group consists of formulas in which the value of hydraulic resistance is determined by the height of protrusions of the roughness $\Delta$ of a channel or average diameter $d$ of soil particles making up the bottom and banks of a river channel, or the height $h_{r}$ and length $l_{r}$ of the river bottom ridges: 


$$
\begin{gathered}
\sim 23 \sim \\
C=f\left(d, \Delta, h_{r}, l_{r}\right) .
\end{gathered}
$$

The third group consists of formulas taking into account the effect of the water surface slope $S_{f}$, as well as the average flow depth $h$ or hydraulic radius $R$ :

$$
C=f\left(S_{f}, h\right), \text { or } C=f\left(S_{f}, R\right)
$$

The fourth group consists of formulas taking into account the influence of the relative width $B / h$ (or $B / R$ ) of flow:

$$
C=f(B / h), \text { or } C=f(B / R)
$$

In addition, a separate implicit formulas group can also be singled out. To determine the coefficient $C$ using them, a trial-and-error procedure (iterative calculation) has to be used.

\subsection{Formulas to calculate the Chézy coefficient $C$ taking into account the roughness coefficient $n$}

Among empirical formulas and relationships of the type of (10) the most frequently cited the Manning, Guanguillet-Kutter, Bazin, Forchheimer, Pavlovskii formulas are [8-10, 29, 34, 52-59, 61, 70-73]. Below, Table 1 shows some of them.

\begin{tabular}{|c|c|c|}
\hline $\begin{array}{l}\text { Formula author } \\
\text { (s), year, } \\
\text { references }\end{array}$ & $\begin{array}{l}\text { Equation to calculate the Chézy } \\
\text { roughness coefficient } C\end{array}$ & $\begin{array}{l}\text { Recommended } \\
\text { usage limits }\end{array}$ \\
\hline 1 & 2 & 3 \\
\hline $\begin{array}{l}\text { Guanguillet, and } \\
\text { Kutter (the G. K. } \\
\text { formula), 1869, } \\
{[8-10,71,73]}\end{array}$ & $\begin{array}{l}\qquad C=\frac{23+0.00155 / S_{f}+1 / n}{1+\left(23+0.00155 / S_{f}\right) \cdot n / \sqrt{R}},(14) \\
\text { where } S_{f} \text { is the water surface slope (hydraulic } \\
\text { slope). }\end{array}$ & $\begin{array}{l}0.1 \leq R \leq 5.0 \mathrm{~m}, \\
S_{f}>0.0005, \\
0.011 \leq n \leq 0.04\end{array}$ \\
\hline $\begin{array}{l}\text { The simplified G. } \\
\text { K. formula, } 1869 \text {, } \\
\text { [71] }\end{array}$ & $C=\frac{23+1 / n}{1+23 n / \sqrt{R}}$ & $S_{f} \leq 0.0005$ \\
\hline $\begin{array}{l}\text { The G. K. formula } \\
\text { approximation by } \\
\text { the exponential } \\
\text { function, } 1890 \text {, } \\
{[8-10,71]}\end{array}$ & $\begin{array}{l}\qquad C=\frac{1}{n} R^{y} \text {, } \\
\text { where } y \text { is the degree indicator modelling the } \\
\text { relationship between the Chézy coefficient } C \\
\text { and the roughness coefficient } n \text {. }\end{array}$ & $\begin{array}{l}0.1 \leq R \leq 5.0 \mathrm{~m} \\
0.011 \leq n \leq 0.04\end{array}$ \\
\hline $\begin{array}{l}\text { Manning, 1890, } \\
{[8-10,71]}\end{array}$ & $C=\frac{1}{n} R^{1 / 6}$ & $\begin{array}{l}0.1 \leq R \leq 5.0 \mathrm{~m} \\
0.011 \leq n \leq 0.04\end{array}$ \\
\hline
\end{tabular}

Table 1 - Formulas to compute the Chézy roughness coefficient $C$ taking into account the roughness coefficient $n$ and hydraulic radius $R$ or average flow depth $h$ 


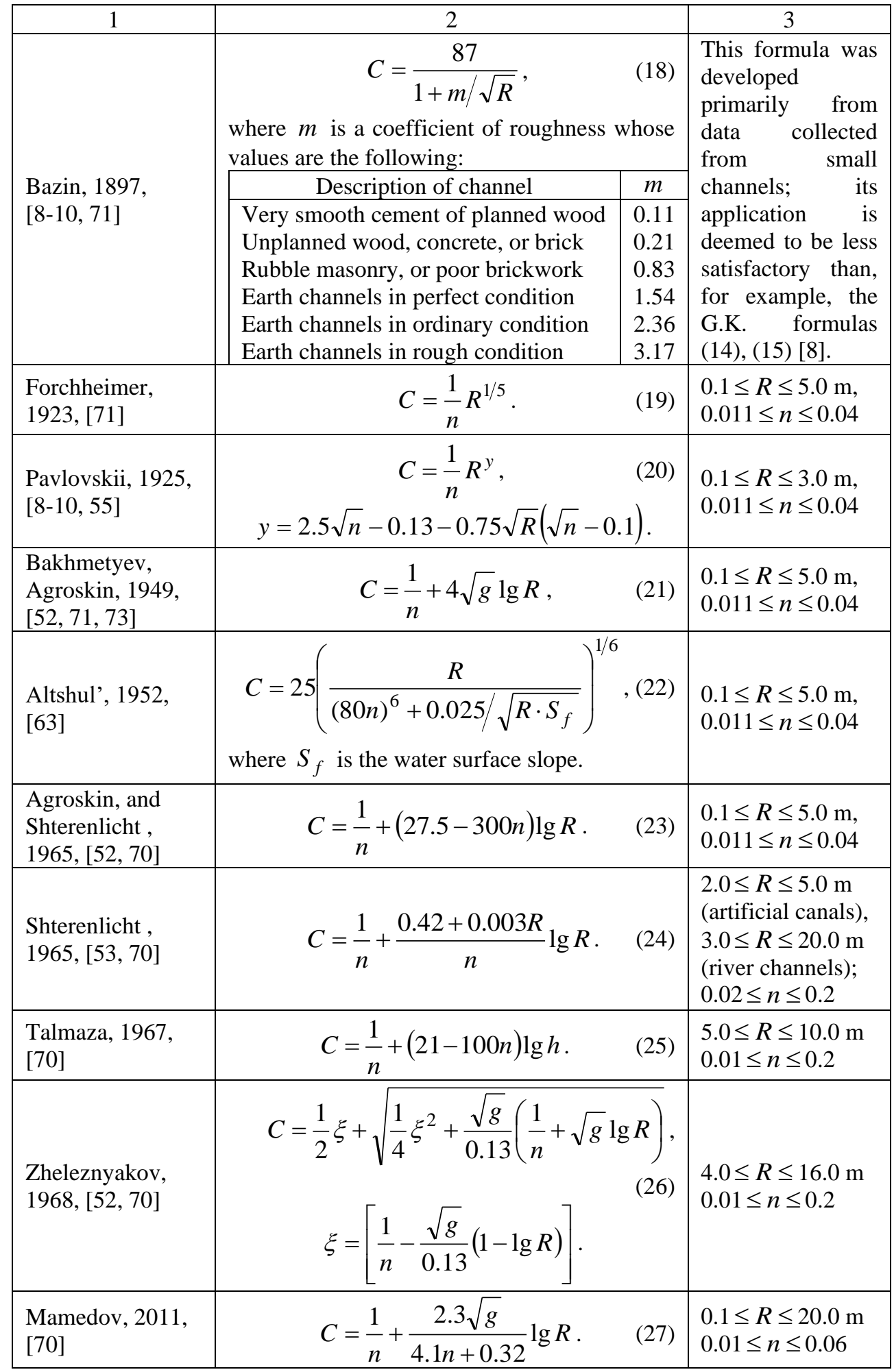

Calculation of the Chézy roughness coefficient $C$ taking into account the roughness coefficient $n$ and hydraulic radius $R$ (or average flow depth $h$ ) stays still 
the main approach to determine the hydraulic resistance of natural channels. Admittedly, however, formulas of the type of (10) including the formulas (14)-(27) are approximate; their accuracy is deemed not high [8-10, 70-73]. First of all, this is because of the variety of river channels, and the fact that each of these formulas best corresponds to the specific flow conditions for which it is derived. However, these formulas can give quite acceptable results. In particular, their accuracy can be significantly improved in the case of preliminary identification of the roughness coefficient $n$ taking account different depths and flow velocities according to current field data [28, 29, 54, 60, 61, 65-70]. Although, it requires significant efforts and time losses and cannot always be applied in practice.

\subsection{Computing the Gauckler - Manning roughness coefficient $n$}

The Gauckler - Manning roughness coefficient $n$ characterizes a measure of the factional resistance exerted by a channel on flow. Its value can also reflect other energy losses, such as those resulting from unsteady flow, extreme turbulence, and transport of suspended material and debris, that are often difficult or impossible to isolate and quantify [54, 65].

An estimated $n$ value can be obtained in one of the following ways [54]:

1) computed (identified) from the $n$-value equation (2) from known water discharge, channel geometry, and water-surface profile; this $n$ value reflects a stagespecific $n$ value with or without increments of roughness attributable to vegetation, obstructions, and other flow-retarding factors;

2) selected from a published $n$-value table [8-10, 54, 65]; usually, this value reflects only the boundary friction from the bed and bank sediments and does not include additive effects from other flow-retarding factors, such as channel-shape variation, random obstructions, and a special vegetation;

3 ) estimated by comparison with photographs of channels for which $n$ values have been pre-computed according to the way (1) [54]; or

4) calculated by means of empirical formulas the relations between flow resistance and hydraulic and particle-size characteristics of stream channels, that are similar to those of the sites having used in the development of these equations.

Below, Table 2 shows similar empirical equations. Some of these formulas may be of considerable practical interest, although they have limited applications because of referring to one-dimensional flow models. The most important factors affecting the $n$ values are the type and size of the materials composing the bed and banks of river channels, vegetation factor, energy gradient and the channel shape.

Table 2 - Formulas to compute the Gauckler - Manning roughness coefficient $n$

\begin{tabular}{|c|c|c|}
\hline $\begin{array}{c}\text { Formula } \\
\text { author (s), } \\
\text { year, } \\
\text { references }\end{array}$ & $\begin{array}{c}\text { Equation to calculate the } \\
\text { Gauckler - Manning roughness } \\
\text { coefficient } n\end{array}$ & \multicolumn{1}{c|}{$\begin{array}{c}\text { Common application } \\
\text { recommendations }\end{array}$} \\
\hline 1 & 2 & 3 \\
\hline $\begin{array}{l}\text { Henderson, } \\
1966,[54]\end{array}$ & $\begin{array}{c}n=0.034 d_{50}^{1 / 6}, \quad(28) \\
\text { where } d_{50} \text { is the median size of } \\
\text { the bed material (feet). }\end{array}$ & $\begin{array}{l}\text { Streams with gravel beds. The } \\
\text { equation is appropriate only for } \\
\text { relatively high within-bank flows. }\end{array}$ \\
\hline
\end{tabular}




\begin{tabular}{|c|c|c|}
\hline 1 & 2 & 3 \\
\hline $\begin{array}{l}\text { Limerinos, } \\
1970,[54,65]\end{array}$ & $\begin{array}{l}n=\frac{0.0926 R^{1 / 6}}{1.16+2.0 \log \left(R / d_{84}\right)},(29) \\
\text { where } R \text { is the hydraulic radius } \\
\text { (feet); } d_{84} \text { is the intermediate } \\
\text { particle diameter (feet), that equals } \\
\text { or exceeds that of } 84 \text { per cent of } \\
\text { the particles; or } \\
\qquad n=\frac{0.8204 R^{1 / 6}}{1.16+2.0 \log \left(R / d_{84}\right)}, \\
\text { where } R, d_{84} \text { are measured in } \\
\text { meters. }\end{array}$ & $\begin{array}{l}\text { Straight channels, relatively wide } \\
\text { and of trapezoidal shape, relatively } \\
\text { free of flow-retarding effects } \\
\text { associated with irregular channel } \\
\text { features and vegetation. The } \\
\text { equation provides the reliable } \\
\text { estimate of } n \text {-values for high } \\
\text { within-bank flows in gravel-bed } \\
\text { channels with small bed-material } \\
\text { transport and insignificant } \\
\text { vegetation. Parameter limits are: } \\
0.02<d_{50}<0.83 \text { (feet); } S_{f}< \\
0.002 ; R<11.0 \text { (feet). }\end{array}$ \\
\hline $\begin{array}{l}\text { Petruk, and } \\
\text { Bosmajian, } \\
\text { 1975, [65] }\end{array}$ & $\begin{array}{l}n=n_{0} \cdot \\
\cdot\left[1+\left(\frac{C_{d} \sum A_{i}}{2 g A \cdot L}\right)\left(\frac{1}{n_{0}}\right)^{2} R^{\frac{4}{3}}\right]^{0.5} \\
\text { where } n_{0} \text { is a base } n \text { value [54], } \\
\text { estimated excluding the effect of a } \\
\text { vegetation; } C_{d} \text { is the effective- } \\
\text { drag coefficient for the vegetation } \\
\text { in the direction of flow; } \sum A_{i} \text { is } \\
\text { the total frontal area of vegetation } \\
\text { blocking the flow in the reach, and } \\
A \text { is the cross-sectional area of } \\
\text { flow }\left(\mathrm{m}^{2}\right) ; \quad L \text { is the length of } \\
\text { channel reach }(\mathrm{m}) \text {. }\end{array}$ & $\begin{array}{l}\text { This formula can be recommended } \\
\text { in the case of densely vegetated } \\
\text { floodplains. }\end{array}$ \\
\hline $\begin{array}{l}\text { Froehlich, } \\
1978,[54]\end{array}$ & $\begin{array}{l}\quad n=0.245 R^{0.14}\left(R / d_{50}\right)^{-0.44} \\
\qquad \cdot(R / B)^{0.30}, \\
\text { where } R \text { is the hydraulic radius, } \\
\text { and } B \text { is the top width of stream } \\
\text { (feet), } d_{50} \text { is the intermediate } \\
\text { particle diameter (feet), that equals } \\
\text { or exceeds that of } 50 \text { per cent of } \\
\text { the particles. }\end{array}$ & $\begin{array}{l}\text { Channels with water surface } \\
\text { slopes between } 0.0003 \text { and } 0.018 \text {, } \\
\text { and } R \leq 19 \text { feet. This equation is } \\
\text { deemed the best to specific } \\
\text { applications, such as estimating } n \\
\text { values on narrow river channels } \\
\text { with dense stream bank } \\
\text { vegetation. }\end{array}$ \\
\hline $\begin{array}{l}\text { Bray, 1979, } \\
\text { [54] }\end{array}$ & $\begin{array}{l}\qquad n=0.104 S_{f}^{0.177}, \\
\text { where } S_{f} \text { is the slope of water } \\
\text { surface (feet per foot). }\end{array}$ & $\begin{array}{l}\text { Parameter limits are: } 0.06<d_{50}< \\
0.48 \text {, feet }(\mathrm{ft}) ; 0.00022<S_{f}< \\
0.015 ; 47<B<1,790 \mathrm{ft} ; 5< \\
h / d_{50}<166 \text {. The equation is } \\
\text { inappropriate for channels, where } \\
\text { the } n \text { value is expected to vary } \\
\text { with the flow depth } h \text {, such as } \\
\text { mountain streams and narrow } \\
\text { channels with dense vegetation. }\end{array}$ \\
\hline
\end{tabular}




\begin{tabular}{|c|c|c|}
\hline 1 & 2 & 3 \\
\hline $\begin{array}{l}\text { Abalyants, } \\
\text { 1981, [57] }\end{array}$ & $\begin{array}{l}\qquad n=1.3 n_{0}(R / B)^{1 / 12} \text {, (33) } \\
\text { where } n_{0} \text { is the roughness } \\
\text { coefficient of flat flow, } R \text { is the } \\
\text { hydraulic radius, and } B \text { is the } \\
\text { width of stream }(\mathrm{m}) \text {. }\end{array}$ & $\begin{array}{l}\text { This formula is useful when one } \\
\text { considers the influence of the } \\
\text { channel section shape. }\end{array}$ \\
\hline $\begin{array}{l}\text { Jarrett, 1984, } \\
{[54,61]}\end{array}$ & $\begin{array}{l}\qquad n=0.32 S_{f}^{0.38} R^{-0.16} \text {, (34) } \\
\text { where } S_{f} \text { is the energy gradient } \\
\text { (feet per foot), and } R \text { is the } \\
\text { hydraulic radius (feet). }\end{array}$ & $\begin{array}{l}\text { Channels with energy gradients } \\
\text { from } 0.002 \text { to } 0.09 \text { and hydraulic } \\
\text { radii from } 0.5 \text { to } 7 \text { feet. The ratios } \\
\text { of hydraulic radius to } d_{50} \\
\left(R / d_{50}\right) \text { are admitted less than } 5 \text {. }\end{array}$ \\
\hline $\begin{array}{l}\text { Kang, } 1985 \text {, } \\
\text { [33] }\end{array}$ & $\begin{array}{l}\qquad n=0.39 h^{0.34} \\
\text { where } h \text { is the flow depth }(\mathrm{m}) \text {. }\end{array}$ & $\begin{array}{l}\text { This formula can be applicable to } \\
\text { debris flows channels. }\end{array}$ \\
\hline $\begin{array}{l}\text { Sauer, 1990, } \\
\text { [54] }\end{array}$ & $\begin{array}{l}\qquad n=0.11 S_{f}^{0.18} R^{0.08} \text {, (36) } \\
\text { where } S_{f} \text { is the slope of water } \\
\text { surface (feet per foot), and } R \text { is } \\
\text { the hydraulic radius (feet). }\end{array}$ & $\begin{array}{l}\text { Application recommendations are } \\
\text { similar to those for the Froehlich } \\
\text { equation (31). }\end{array}$ \\
\hline $\begin{array}{l}\text { Fisher, 1992, } \\
\text { [67] }\end{array}$ & $\begin{array}{l}\qquad n=n_{0}+0.0239\left(\frac{B_{v}}{V \cdot R}\right), \text { (37) } \\
\text { where } n_{0} \text { is a base } n \text { value [54] } \\
\text { estimated excluding the effect of a } \\
\text { vegetation; } B_{v} \text { is the volumetric } \\
\text { blockage factor (m); } V \text { is the } \\
\text { averaged velocity across flow } \\
\text { depth }(\mathrm{m} / \mathrm{s}) ; R \text { is the hydraulic } \\
\text { radius }(\mathrm{m}) \text {. }\end{array}$ & $\begin{array}{l}\text { It is assumed that each sub-area is } \\
\text { entirely filled with vegetation of } \\
\text { uniform height. With this } \\
\text { assumption, the volumetric } \\
\text { blockage factor is accepted as } \\
\text { equal to the ratio of vegetation } \\
\text { height to flow depth. }\end{array}$ \\
\hline $\begin{array}{l}\text { Reed et al., } \\
1995,[67]\end{array}$ & $\begin{array}{l}\qquad n=\beta / \sqrt{h}, \\
\text { where } h \text { is the flow depth }(\mathrm{m}), \beta \\
\text { is the vegetation resistance } \\
\text { parameter }\left(\mathrm{s} \cdot \mathrm{m}^{1 / 6}\right) .\end{array}$ & $\begin{array}{l}\text { The } \beta \text { value is: low density } \\
\text { vegetation, and } h>0.3 \mathrm{~m}, \beta= \\
0.4 \text {; moderately dense vegetation, } \\
\text { and } h=0.3 \mathrm{~m}, \beta=1.6 \text {; very } \\
\text { dense vegetation, and } h<0.3 \mathrm{~m} \text {, } \\
\beta=6.4 \text {. }\end{array}$ \\
\hline Fei, 2003, [33] & $\begin{array}{l}\frac{1}{n}=1.62\left[\frac{s_{v}\left(1-s_{v}\right)}{\sqrt{h \cdot S_{f} \cdot D_{10}}}\right]^{\frac{2}{3}},(39) \\
\text { where } s_{v} \text { is the solid volume } \\
\text { concentration of the debris flow; } \\
h \text { is the flow depth (m); } S_{f} \text { is the } \\
\text { hydraulic gradient (hydraulic } \\
\text { slope); } D_{10} \text { is the characteristic } \\
\text { grain size for which } 10 \text { per cent of } \\
\text { the bed material is finer in } \\
\text { diameter }(\mathrm{m}) \text {. }\end{array}$ & $\begin{array}{l}\text { This formula can be applicable to } \\
\text { debris flows channels. }\end{array}$ \\
\hline
\end{tabular}




\begin{tabular}{|l|c|c|}
\hline 1 & \multicolumn{1}{|c|}{$n=0.083\left(\frac{d_{84}}{R}\right)^{0.55}+$} & \\
\hline $\begin{array}{l}\text { Zhu et al., } \\
\text { 2020, [33] }\end{array}$ & $+0.0075\left(\frac{h}{d_{50}}\right)^{0.70} s_{v}^{1.45} S_{f}^{0.66}$, & This formula can be applicable to \\
& $\begin{array}{l}\text { where, see also (39), } R \text { is the } \\
\text { hydraulic radius (m); } h \text { is the flow } \\
\text { depth (m); } d_{84} \text { and } d_{50} \text { are } \\
\text { particle diameters (m). }\end{array}$ & \\
\hline
\end{tabular}

Values of the roughness coefficient $n$ obtained by means of formulas (28)-(40) may be assigned to conditions that exist at the time of a specific flow event, to average conditions over a range in stage, or to anticipated conditions at the time of a future event. However, roughness values for floodplains can be essentially different from values for channels; therefore, roughness values for floodplains should be determined independently from channel values [65]. For that, there are appropriate analytical procedures that enable considering morphological heterogeneity of channel roughness, in particular, along the channel perimeter, as well as adjustment factors of $n$ values for floodplains [8-10, 65].

\subsection{Formulas to calculate the Chézy coefficient $C$ taking into account the size of protrusions of the roughness and bottom ridges}

Formulas considering the effect of the protrusions roughnesses on the Chézy coefficient are usually proposed for mountainous and foothills rivers. In turn, the influence of hydraulic resistance of bottom ridges is taken into account in the formulas being developed mainly for large canals and plain rivers, where there are conditions to exist of the bottom ridge phase of sediment movement.

In the practically non-erosion rivers channels, the roughness of the protrusions is usually estimated by the height of the protrusions $\Delta$ or the parameters $h / \Delta$, $\varepsilon=\Delta / h$, where $h$ is the average depth of flow.

In the case of the erosion channels characterizing by dynamic morphological changes in their structure, hydraulic resistances are determined by both the roughness of bottom sediment particles and structural channel formations such as riffles, ridges, dunes, etc. The last ones have certain sizes and different shapes and characterizing by certain mobility $[52,56,57]$. Therefore, in general, there can be revealed two types of the river channel bottom roughness. The first type concerns micro-roughness characterizing by the size of the bottom fractions of sediments. The second type includes macro-roughness forms characterizing by the size of the bottom ridge formations. Then, the Chézy coefficient for a certain channel section taking into account the micro- and macro-roughness can be written as [52, 53, 57]:

$$
\frac{1}{C^{2}}=\frac{1}{C_{\Delta}^{2}}+\frac{1}{C_{r}^{2}},
$$


where $C_{\Delta}$ is the Chézy coefficient component accounting for the influence of hydraulic resistance due to the micro-roughness of the bottom fractions of sediments, and $C_{r}$ is the Chézy coefficient component accounting for the influence of hydraulic resistance due to the macro-roughness of bottom ridge formations.

In more general cases, the formula (41) may be supplemented by other components to consider the effects of vegetation, ice cover, channel meandering, and other factors [52-54, 57, 65].

Below, Table 3 shows some empirical formulas to calculate the Chézy roughness coefficient $C$ taking into account the size of protrusions of the roughness and parameters of bottom ridges according to (11). It should be noted, in deriving most of the formulas of the type of (11), the Darcy - Weisbach empirical equation (3) with the transformation (5) had been used.

Table 3 - Formulas to calculate the Chézy roughness coefficient $C$ taking into account the size of protrusions of the roughness and parameters of bottom ridges

\begin{tabular}{|c|c|c|}
\hline $\begin{array}{l}\text { Formula author } \\
\text { (s), year, } \\
\text { references }\end{array}$ & $\begin{array}{l}\text { Equation to calculate the Chézy } \\
\text { roughness coefficient } C\end{array}$ & $\begin{array}{l}\text { Common application } \\
\text { recommendations }\end{array}$ \\
\hline 1 & 2 & 3 \\
\hline $\begin{array}{l}\text { Strickler, } 1923, \\
{[56,57,73]}\end{array}$ & $\begin{array}{l}\qquad C_{\Delta}=6.67 \sqrt{g}(R / \Delta)^{1 / 6}, \\
\text { where } R \text { is the hydraulic radius }(\mathrm{m}), \Delta \\
\text { is the height of protrusions }(\mathrm{m}) \text {. }\end{array}$ & $\begin{array}{l}\Delta=d, \text { where } d \text { is the } \\
\text { average diameter of the } \\
\text { bottom sediments. }\end{array}$ \\
\hline $\begin{array}{l}\text { Colebrook, and } \\
\text { White, 1937, [59] }\end{array}$ & $C_{\Delta}=18 \log (12 R / \Delta)$ & $\begin{array}{l}\text { Rivers with rough } \\
\text { turbulent flows. }\end{array}$ \\
\hline $\begin{array}{l}\text { Makkaveev, 1947, } \\
\text { [74] }\end{array}$ & $\begin{array}{l}\qquad C_{\Delta}=3.015 \sqrt{g}\left(\frac{h}{\Delta}\right)^{1 / 6} \\
\text { where } h \text { is the average depth of flow and } \\
\Delta \text { is the height of protrusions }(\mathrm{m}) \text {. }\end{array}$ & $\begin{array}{l}\Delta=d, \text { where } d \text { is the } \\
\text { average diameter of the } \\
\text { bottom sediments. }\end{array}$ \\
\hline $\begin{array}{l}\text { Williamson, 1951, } \\
\text { [62] }\end{array}$ & $\begin{array}{l}\qquad \lambda=0.113(\Delta / R)^{1 / 3} \\
C_{\Delta}=\sqrt{8 g / \lambda}, \text { where } \lambda \text { is the Darcy - } \\
\text { Weisbach friction factor. }\end{array}$ & $\begin{array}{l}\Delta=d, \text { where } d \text { is the } \\
\text { average diameter of the } \\
\text { bottom sediments. }\end{array}$ \\
\hline $\begin{array}{l}\text { Goncharov, 1955, } \\
{[52,56,57]}\end{array}$ & $\begin{array}{l}\qquad C_{\Delta}=4 \sqrt{2 g} \lg \frac{6.15 R}{\Delta} \text {, (46) } \\
\text { where } R \text { is hydraulic radius }(\mathrm{m}) \text {, and } \Delta \\
\text { is the height of protrusions (m). }\end{array}$ & $\begin{array}{l}\text { For bed sediments } \\
\text { forming bed paving } \Delta \\
=0.5 d_{50} ; \text { for soils } \\
\text { carried by the flow } \Delta= \\
0.7 d_{5} \text {. }\end{array}$ \\
\hline $\begin{array}{l}\text { Zegzhda, } 1957, \\
{[52,56,57]}\end{array}$ & $\begin{array}{l}\qquad \frac{C_{\Delta}}{\sqrt{8 g}}=4 \lg \frac{h}{\Delta}+4.25 \\
\text { where } h \text { is the average depth of flow. }\end{array}$ & $\begin{array}{l}\text { Small rivers with } \\
\text { rectangular-shaped } \\
\text { channels. }\end{array}$ \\
\hline $\begin{array}{l}\text { Knoroz, } 1960, \\
{[52,56,57]}\end{array}$ & $\begin{array}{l}\qquad C_{r}=3.16 \sqrt{g}\left(\frac{R}{h_{r}}\right)^{1 / 8}\left(\frac{l_{r}}{h_{r}}\right)^{1 / 2} \text {, (48) } \\
\text { where } h_{r} \text { is the height }(\mathrm{m}), l_{r} \text { is the } \\
\text { length of bottom ridges }(\mathrm{m}) \text {. }\end{array}$ & $\begin{array}{l}\text { Rivers with scaly- } \\
\text { shaped ridges with } \\
\text { developed turbulent } \\
\text { zones within small sand } \\
\text { channels. }\end{array}$ \\
\hline
\end{tabular}




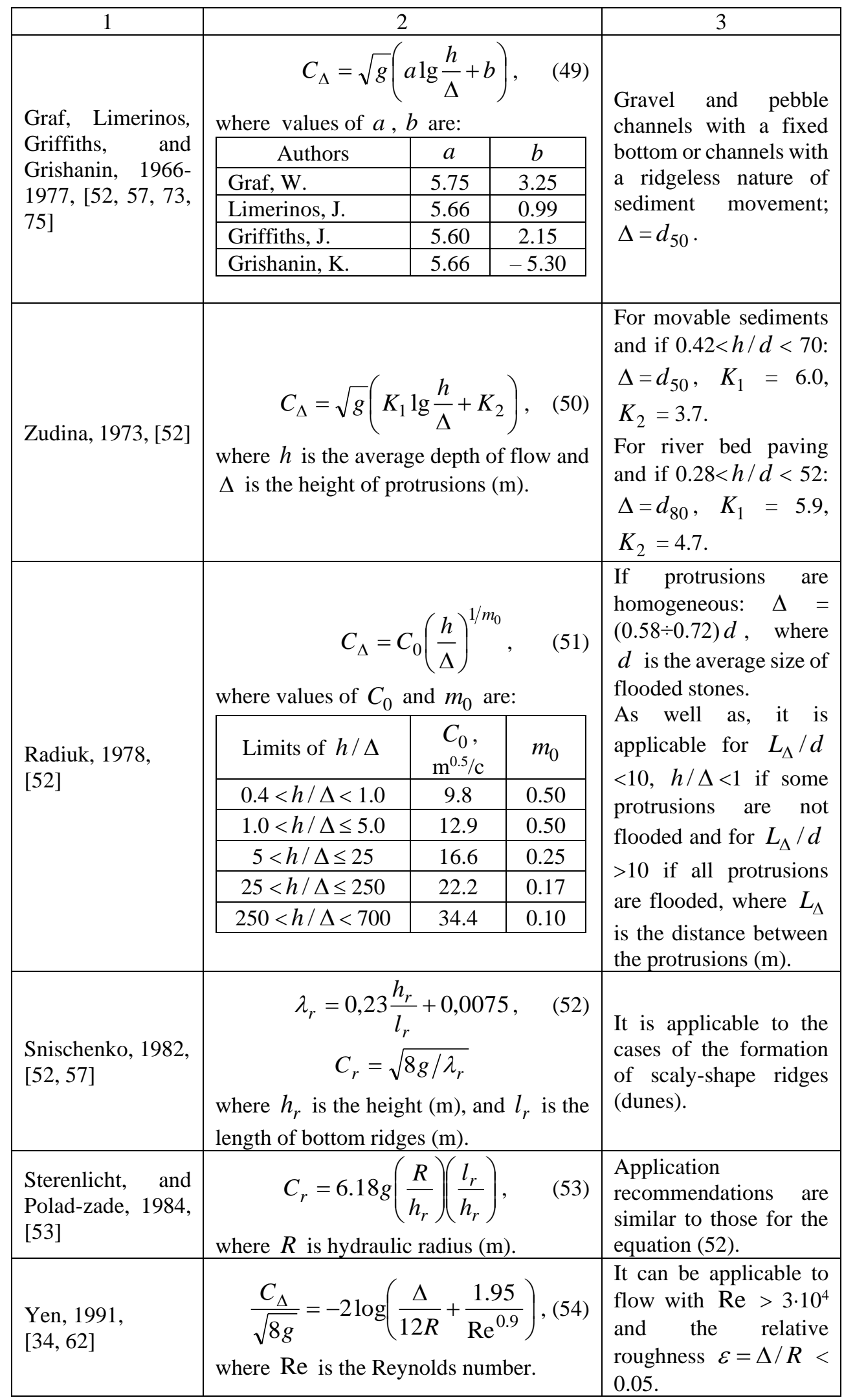




\begin{tabular}{|l|l|l|}
\hline \multicolumn{1}{|c|}{2} & \multicolumn{1}{|c|}{2} \\
\hline Fenton, 2010, \\
{$[34,62]$}
\end{tabular}$\quad \begin{aligned} & \frac{C_{\Delta}}{\sqrt{8 g}}=-2 \log \left(\frac{\Delta}{12 R}+\left(\frac{2}{\operatorname{Re}}\right)^{0.9}\right),(55) \\
& \begin{array}{l}\text { where } R \text { is hydraulic radius and } \Delta \text { is the } \\
\text { height of protrusions (m); Re is the } \\
\text { Reynolds number. }\end{array}\end{aligned}$\begin{tabular}{l}
$\begin{array}{l}\text { Application } \\
\text { recommendations are } \\
\text { similar to those for the } \\
\text { Yen equation (54). }\end{array}$ \\
\hline
\end{tabular}

Most of the formulas listed in Table 3 have quite limited applications in practice. To get better results, the coefficients of these equations should be corrected based on data from detailed field investigations.

\subsection{Formulas to calculate the Chézy coefficient $C$ taking into account the effect of the water surface slope $S_{f}$}

Admittedly, the adequate determination of the roughness coefficient $n$, as well as of protrusions of the channel roughness or the size of sediment ridges is one of the most difficult problems in open channel hydraulics. Therefore, researchers try developing formulas to determine the Chézy coefficient $C$ that not contain above-mentioned parameters. One approach is to use the water surface slope (hydraulic slope) $S_{f}$ as a determining parameter. The idea is the Chézy coefficient does depend on this parameter, and, sometimes, it does significantly. Eventually, the water surface slope $S_{f}$ is used explicitly in many formulas determining the Chézy coefficient $C$ and the roughness coefficient $n$.

Practice shows, when assessing the hydraulic resistance characteristics for open-channel flows, it is especially important to take into account the hydraulic slope in the case of unstable channels. Numerous field studies have revealed repeatedly, the water flow in unstable channels is able to arbitrarily change the size of protrusions of the roughness of movable bottom, to convert the movement of sediments from ridge-free to the bottom-ridge movement, and vice versa, as well as build or restore channel bed [52]. As a result, the hydraulic resistance of a river channel can change dynamically, and then the water surface slope, which integrally takes into account the influence of various hydro-morphological factors on hydraulic resistance, can appear to be a more informative hydraulic resistance characteristic, than, for example, the roughness coefficient $n$. Table 4 shows several formulas of the type of (12).

Table 4 - Formulas to calculate the Chézy roughness coefficient $C$ taking into account the effect of the water surface slope $S_{f}$

\begin{tabular}{|c|c|c|}
\hline $\begin{array}{c}\text { Formula author } \\
\text { (s), year, } \\
\text { references }\end{array}$ & $\begin{array}{c}\text { Equation to calculate the Chézy } \\
\text { roughness coefficient } C\end{array}$ & $\begin{array}{c}\text { Common application } \\
\text { recommendations }\end{array}$ \\
\hline 1 & 2 & \multicolumn{1}{|c|}{3} \\
\hline $\begin{array}{l}\text { Matachievitch, } \\
1911,[76,77]\end{array}$ & $C=35.4 h^{0,2} S_{f}^{10 S_{f}-0,007, \quad(56)}, \begin{array}{l}\text { Relatively stable self- } \\
\text { regulating river } \\
\text { channels. }\end{array}$ \\
\hline
\end{tabular}




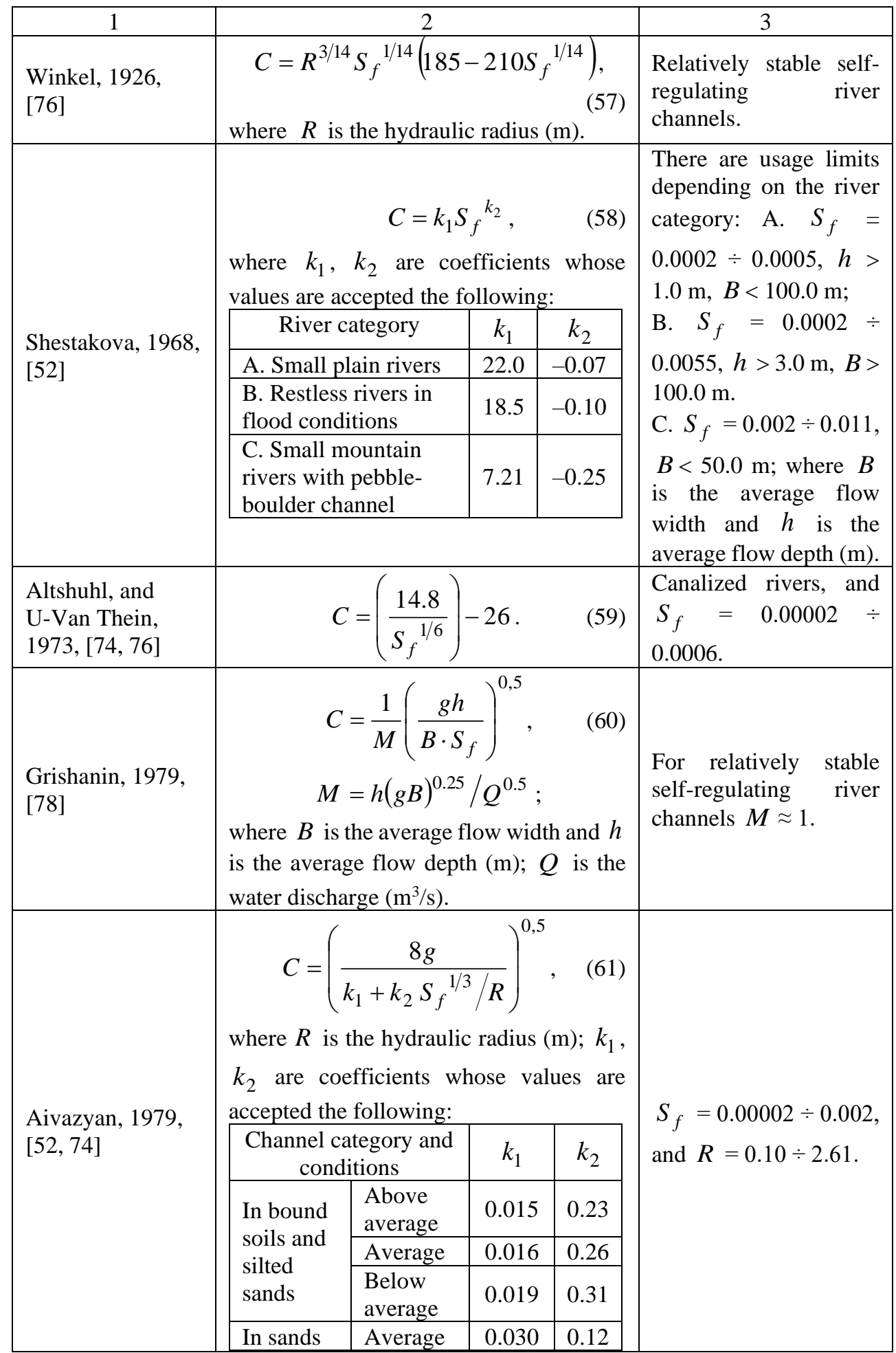

In general, there are some difficulties in choosing an acceptable empirical formula to calculate the Chézy coefficient $C$, which does not contain channel 
roughness parameters. However, it is quite possible to choose similar formulas being effective for partial cases.

\subsection{Formulas to calculate the Chézy coefficient $C$ taking into account the influence of the relative width $B / h$ or $B / R$ of flow}

As practice shows, the shape of channel cross-sections can also affect significantly hydraulic resistances to open flow in rivers. However, since, the cross-sections shapes of river channels can be very diverse, the formal quantitative assessment of their impact on hydraulic resistances is a significant challenge.

In order to simplify the task, the shape of a river channel cross-section is usually estimated by the ratio of the width $B$ to the hydraulic radius $R(B / R)$, or by the ratio of the width $B$ to the average depth $h(B / h)$ of flow. Thereby, a uniform open flow with an arbitrary cross-sectional shape is reduced to a flat flow with depth $h=R$. Table 5 shows several formulas of the type of (13).

Table 5 - Formulas to calculate the Chézy roughness coefficient $C$ taking into account the relative width $B / h$ or $B / R$ of flow

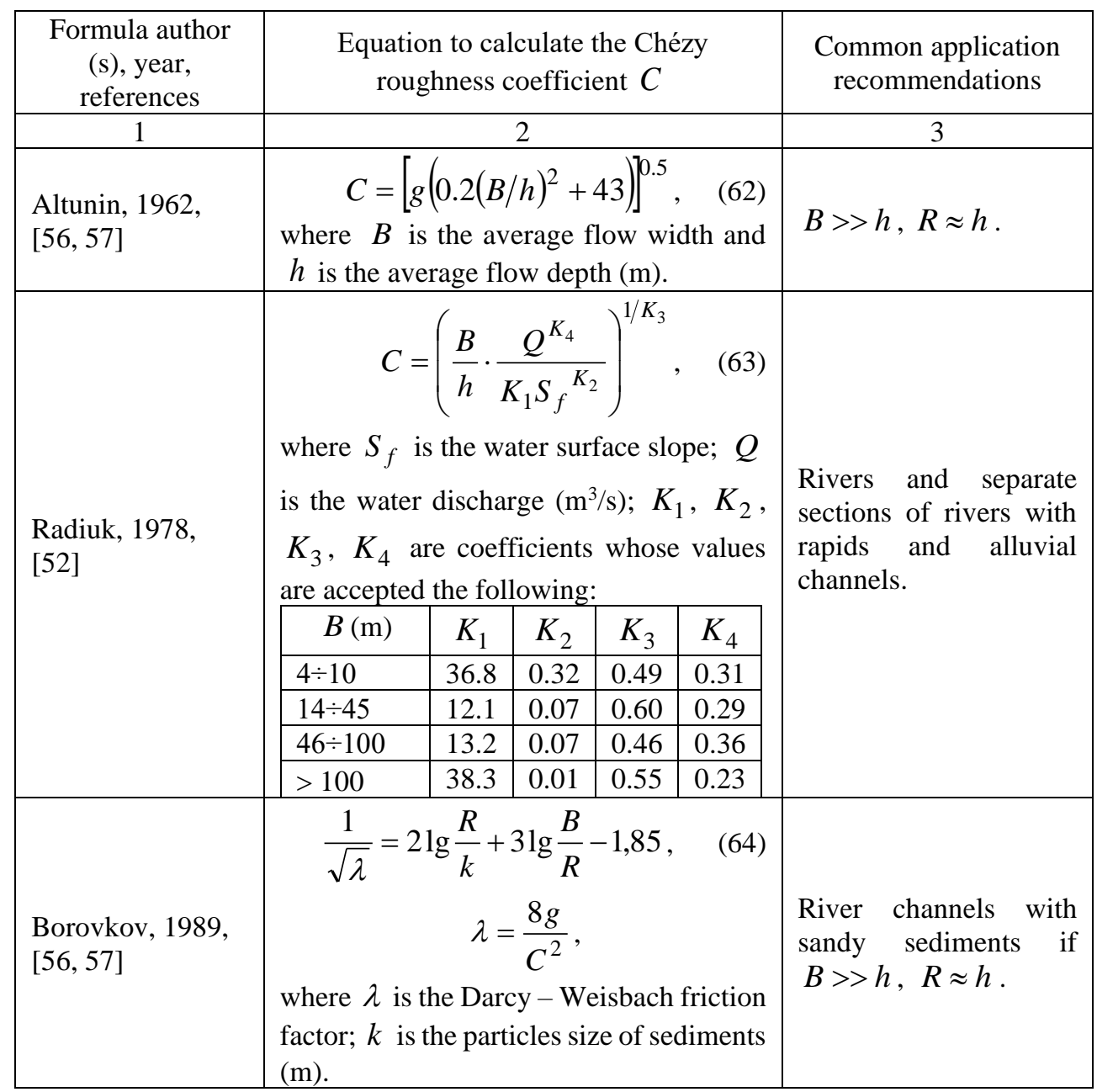




\begin{tabular}{|c|c|c|}
\hline 1 & 2 & 3 \\
\hline $\begin{array}{l}\text { Simanovich, } \\
\text { 1998, [56, 57] }\end{array}$ & $\begin{array}{l}C=0.78 C_{0}+\frac{0.000464 C_{0}^{3}}{g((B / h)-2 \tilde{a}) P}, \\
\text { where } C_{0} \text { is the Chézy coefficient for } \\
\text { conditions of a flat flow; it can be } \\
\text { determined according to formulas of the } \\
\text { type of }(10) ; \tilde{a} \text { is the relative width of the } \\
\text { wall layer; } P \text { is the probability of } \\
\text { exchanging the amount of motion. }\end{array}$ & $\begin{array}{l}\text { It is accepted the more } \\
\text { homogeneous the flow } \\
\text { is the smaller value of } \\
\text { the probability } P \text { is } \\
\text { appointed. }\end{array}$ \\
\hline
\end{tabular}

Table 5 shows the simplest formulas that can be used to calculate the Chézy coefficient taking into account the relative flow width. The formula (63) can also be very useful to identify the Chézy roughness coefficient $C$ based on measured values of $B, h, S_{f}$, and $Q$.

\subsection{Implicit empirical formulas to calculate the Chézy coefficient $C$}

Table 6 shows a few implicit empirical formulas used to calculate the Chézy roughness coefficient $C$ depending on different parameters. These formulas are mentioned in the literature most often (see, [28, 51, 52, 62, 71, 79]).

Table 6 - Examples of implicit empirical formulas to calculate the Chézy roughness coefficient $C$

\begin{tabular}{|c|c|c|}
\hline $\begin{array}{l}\text { Formula author } \\
\text { (s), year, } \\
\text { references }\end{array}$ & $\begin{array}{l}\text { Equation to calculate the Chézy } \\
\text { roughness coefficient } C\end{array}$ & $\begin{array}{l}\text { Common application } \\
\text { recommendations }\end{array}$ \\
\hline 1 & 2 & 3 \\
\hline $\begin{array}{l}\text { Colebrook, and } \\
\text { White, 1937, } \\
{[28,51,62]}\end{array}$ & $\begin{array}{l}\quad \frac{1}{\sqrt{\lambda}}=-2 \log \left(\frac{\Delta}{12 R}+\frac{2.5}{\operatorname{Re} \sqrt{\lambda}}\right), \\
\qquad \lambda=\frac{8 g}{C^{2}}, \\
\text { where } \lambda \text { is the Darcy }- \text { Weisbach friction } \\
\text { factor; } R \text { is the hydraulic radius (m); } \Delta \\
\text { is the height of protrusions (m); Re is the } \\
\text { Reynolds number. }\end{array}$ & $\begin{array}{l}\text { For partly rough } \\
\text { turbulent flows. }\end{array}$ \\
\hline $\begin{array}{l}\text { Thijsse, 1949, } \\
\text { [79] }\end{array}$ & $\begin{array}{l}\qquad C=-18 \log \left(\frac{\Delta}{12 R}+\frac{C}{3 \operatorname{Re}}\right) \\
\text { where } \Delta \text { is the absolute roughness (m); } \\
R \text { is the hydraulic radius }(\mathrm{m})\end{array}$ & $\begin{array}{l}\text { For the entire domain of } \\
\text { turbulent flows. }\end{array}$ \\
\hline $\begin{array}{l}\text { Powell, 1950, } \\
{[8,71]}\end{array}$ & $\begin{array}{l}\qquad C=-42 \log \left(\frac{C}{4 \operatorname{Re}}+\frac{\Delta}{R}\right), \\
\text { where } \Delta \text { is the absolute roughness }(\mathrm{m}) ; \\
R \text { is the hydraulic radius }(\mathrm{m}) ; \mathrm{Re} \text { is the } \\
\text { Reynolds number. }\end{array}$ & $\begin{array}{l}\text { For the entire domain of } \\
\text { turbulent flows. }\end{array}$ \\
\hline
\end{tabular}




\begin{tabular}{|c|c|c|}
\hline 1 & 2 & 3 \\
\hline $\begin{array}{l}\text { Artamonov, } \\
\text { Kroshkin, and } \\
\text { Talmaz, 1972, } \\
{[52]}\end{array}$ & $\begin{array}{l}C_{\Delta}=7.4 K \sqrt{g}\left(\frac{h}{\Delta}\right)^{1 / m}, \\
K=\frac{m-1,5}{m+1} \lg \left(\left(31 \frac{h}{\Delta}+2\right) /\left(\frac{h}{\Delta}+2\right)\right), \\
m=\frac{C_{\Delta}}{\sqrt{g}}\left(\frac{2 \sqrt{g}}{\sqrt{g}+C_{\Delta}}+0,3\right), \\
\text { where } h \text { is the average depth of flow (m), } \\
\Delta \text { is the height of protrusions of the } \\
\text { roughness (m). }\end{array}$ & $\begin{array}{l}\text { Parameter limits: } \\
\Delta=d_{b} \text {, where } d_{b} \text { is } \\
\text { the weighted average } \\
\text { diameter of sediments } \\
\text { in the river bed paving; } \\
h / \Delta=1 \div 1000 ; m>1,5 \text {. }\end{array}$ \\
\hline $\begin{array}{l}\text { Agroskin, and } \\
\text { Zheleznyakov, } \\
\text { 1981, [52] }\end{array}$ & $\begin{array}{l}\qquad C=\frac{1}{n}+\frac{\sqrt{g}+C}{1+0.13 C / \sqrt{g}} \lg R, \text { (70) } \\
\text { where } n \text { is the Manning roughness } \\
\text { coefficient }\left(\mathrm{s} / \mathrm{m}^{1 / 3}\right) ; R \text { is the hydraulic } \\
\text { radius }(\mathrm{m}) \text {. }\end{array}$ & $\begin{array}{l}\text { Parameter limits: } \\
0.1 \leq R \leq 5.0 \mathrm{~m} \\
0.011 \leq n \leq 0.04\end{array}$ \\
\hline
\end{tabular}

Although implicit formulas necessitate an iterative calculation method usage, they can be successfully implemented in practice in mathematical modelling of open flows. In particular, when using implicit formulas, the corresponding explicit formulas, which involve the same parameters as implicit equations do, can be used to obtain first approximations of the Chézy coefficient estimations. Such an approach can appear to be quite useful to optimize the iterative process.

\section{Discussion}

In general, there is no ideal way or method to determine the Chézy roughness coefficient. Among the main challenges to be highlighted there is the uncertainty of hydro-morphological changes associated with sedimentation and erosion activity of natural watercourses, and the seasonal changes in aquatic and coastal vegetation including those of floodplains. As well as, the hydraulic resistance can depend on space-time changes of other hydraulic characteristics. Practical experience and possible options analysis considering different empirical formulas used to estimate the hydraulic resistance to open flows, as well as the comprehensiveness of field researches can have a key role when estimating of the Chézy coefficient. The assessment of the accuracy of the Chézy coefficient computing based on field data according to different methods and formulas indicates that the accuracy of field measurements of the parameters included in selected formulas largely determines the relative error of the calculations.

Calibration studies show that quite reliable results can be obtained using the formulas by Manning (17), Forchheimer (19), Pavlovskii (20), Agroskin (21), Zheleznyakov (26), Mamedov (27), Matachievitch (56), Winkel (57) [8-10, 52-54, 56, 57, 70, 71, 73, 74, 77]. These are the formulas of the type of (10) and (12), namely: $C=f(n, R)$ or $C=f(n, h)$, and $C=f\left(S_{f}, h\right)$ or $C=f\left(S_{f}, R\right)$. They may be considered the most effective ones among the simplest empirical formulas to calculate the Chézy coefficient $C$. Perhaps, it is because the parameters $n$ and $S_{f}$ 
are complex ones and the most complete by effects among all parameters, which reflect influence of different hydro-morphological factors on the hydraulic resistance to flows in river channels.

All the above-shown formulas can be quite reliable and give calculated results with the practically acceptable accuracy provided the high accuracy for all gauged hydro-morphological parameters, as well as the compliance of recommended conditions and limits application. Although, whatever, the relative error in calculating the Chézy coefficient values according to a majority of formulas in comparison to the results of their identification based on measurements of water flow at gauges is rarely less than 15 per cent.

A promising approach to compute the Chézy coefficient in some sections of a river may be using dependencies taking into account the water surface slope $S_{f}$. It is because the accuracy of the water surface slope determination depends on the accuracy of water level measurements; whereas they are the simplest element of the river flow in terms of direct measurements. In the field condition, the absolute error of measuring water levels in rivers at water gauges is usually $1 \mathrm{~cm}$.

In general, the accuracy of water level measurements depends on the accuracy of hydrometric reference heights and the sufficient duration of water level observations to take into account their possible pulsations, which is especially important for mountain streams. This may explain the discrepancy in the values of water surface slopes obtained at different times by different expeditions including the modern GNSS technology usage. In particular, when using the GNSS technology in mountainous conditions, a challenge is if semi-enclosed horizons are explored. In turn, the binding of hydrometric sites, according to Ukraine's standards, is usually performed by means of levelling of the 4th class, which allows an error of $50 \mathrm{~mm}$ $\sqrt{L}$, where $L$ is the length of the levelling course $(\mathrm{km})$. Obviously, one of the problems of ensuring the proper accuracy of the determination of water surface slopes may be the insufficient density of the network of hydrometric observations. When constructing this network and determining the water surface slopes on certain sections of a river, it is also necessary to take into account the peculiarities of the fluvial-morphological process. For example, our experience shows, for river channel areas with a length of more than $5 . .7$ lengths of their mesoforms, the value of the weighted average water surface slope should be used, instead of its average value between sites.

For rapid stream rivers, water level pulsations can also have a noticeable effect on the accuracy of determining water levels. The problems of their influence on the accuracy of determining water levels on rapid stream rivers were studied in detail in the 60s of the last century by O.N. Borsuk [80]. In particular, he found that with increasing the duration of measurements from 2 to 5 minutes, the error of water level measurements decreases significantly. Therefore, water levels on mountainous rivers should be measured at least 20 times in 5-10 minutes, so that the average error of their measurements does not exceed $1 \mathrm{~cm}$.

\section{Conclusions}

1. In many cases, the accuracy of determining the hydraulic resistance characteristics can largely affect the accuracy of solving tasks relating to designing hydraulic structures and water management of rivers regardless of chosen mathematical 
models or methods. Rivers are characterized by a significant variety of flow conditions, so hydraulic resistance to flows in rivers can vary widely determining their flow capacity. Considering the variety of river hydro-morphology and hydrology, the Chézy roughness coefficient appears to be the most complete characteristic of hydraulic resistance to open flows in river channels comparing with other corresponding integral empirical characteristics.

2. There are a large number of empirical and semi-empirical formulas to calculate the Chézy roughness coefficient. In general, all the existing empirical formulas and dependencies used to calculate the Chézy coefficient can be divided and systematized into four main groups. The first group consists of formulas in which mostly there is established the dependence of the Chézy coefficient on the roughness coefficient including, sometimes, the hydraulic radius or the average flow depth. The second group consists of formulas in which the value of hydraulic resistance is determined by the height of protrusions of the roughness of a channel or average diameter of soil particles making up the bottom and banks of the channel, or the height and length of bottom ridges. The third group consists of formulas taking into account the effect of the water surface slope and average flow depth or hydraulic radius. The fourth group consists of formulas taking into account the influence of the relative width $B / h$ (or $B / R$ ) of flow. Separately, an implicit formulas group can also be singled out. To determine the Chézy coefficient by those formulas, a trialand-error procedure has to be used.

3. In total, 43 formulas to calculate the Chézy roughness coefficient, as well as 13 formulas that can be used to estimate the Manning roughness coefficient were analyzed and systematized. Based on these formulas, about 250 empirical equations can be compiled to calculate the Chézy coefficient depending on hydromorphological peculiarities of rivers and river channels, hydraulic conditions, formula application limits, and so on.

4. Practical experience and options analysis considering different approaches, methods, and empirical formulas used to estimate the hydraulic resistance to open flows, as well as the comprehensiveness of field researches can have a key role in reliable estimating of the Chézy coefficient. The assessment of the accuracy of the Chézy coefficient calculation based on field data according to different methods and formulas indicates that the accuracy of field measurements of the parameters included in selected formulas largely determines the relative error of calculations.

\section{REFERENCES}

1. Abbott, P. L. (1996). Natural Disasters. Wm. C. Brown Publishing Co, 438 p.

2. Korbutiak, V., Stefanyshyn, D., Lahodniuk, O., and Lahodniuk, A. (2020). The combined approach to solving issues of the flood hazard assessment using water gauge records and spatial data. Acta Sci. Pol. Architectura, 19 (1), 111-118; DOI: https://doi.org/10.22630/ASPA.2020.19.1.12.

3. Hydropower Status Report. Sector trends and insights. (2020). IHA. Available from https://www.hydropower.org/publications/2020-hydropower-status-report.

4. Riverine Ecosystem Management. Science for Governing Towards a Sustainable Future. (2018). Schmutz, S., and Sendzimir, J., Editors. Aquatic Ecology Series. Volume 8. Springer Open, $562 \mathrm{p}$.

5. Kakoyannis, Ch., and Stankey, G.H. (2002). Assessing and evaluating recreational uses of water resources: implications for an integrated management framework. Gen. Tech. Rep. 
PNW-GTR-536. Portland, OR: U.S. Dep. of Agriculture, Forest Service, Pacific Northwest Research Station, $59 \mathrm{p}$.

6. River tourism. (2009). Ed. by Prideaux, B., and Cooper, M. Oxfordshire: CABI Publishing, $269 \mathrm{p}$.

7. Kummu, M., de Moel, H., Ward, and P.J., Varis, O. (2011). How Close Do We Live to Water? A Global Analysis of Population Distance to Freshwater Bodies. PLoS ONE 6(6): e20578; https://doi.org/10.1371/journal.pone.0020578.

8. Chow, V.T. (1959). Open-channel hydraulics. N.Y., McGraw-Hill, 680 p.

9. French, R.H. (1986). Open-channel hydraulics. N.Y., McGraw-Hill, 705 p.

10. Sturm, T.W. (2001). Open Channel Hydraulics. McGraw-Hill, N.Y., 493 p.

11. Introduction to hydrology. (1975). First ed. by W., Viessman, Jr., T. E., Harbaugh, and J. W., Knapp. Intext ed. publishers. N.Y., London, 704 p.

12. Mujumdar, P.P. (2001). Flood wave propagation. Reson 6, 66-73; https://doi.org/10.1007/BF02839085.

13. Veksler, A.B., Ivashintsov, D.A., and Stefanishin, D.V. (2002). Reliability, social and environmental safety of hydraulic structures: risk assessment and decision making. St. Petersburg: VNIIG B.E. Vedeneeva, 591 p. (in Russian).

14. Ponce, V.M., Taher-shamsi, A., and Shetty, A.V. (2003). Dam-Breach Flood Wave Propagation Using Dimensionless Parameters. Journal of Hydraulic Engineering, Vol. 129, Issue 10, 777-782; DOI: https://doi.org/10.1061/(ASCE)0733-9429(2003)129:10(777).

15. River channels: environment and processes. (1987). Institute of British Geographers Special Publications. By K., Richards. Wiley-Blackwell, 400 p.

16. Julien, P.Y. (2002). River Mechanics. Cambridge University Press, UK, 456 p.

17. Schodro, A.E. (2007). River Bed Deformations Near Banks and Hydraulic Structures due to River Flow. Proc. of $4^{\text {th }}$ Int. Conf. on River Basin Management Including all Aspects of Hydrology, Ecology, Environmental Management, Flood Plains and Wetlands. WIT-Press, Southampton, Boston, 381-387.

18. Khodnevich, Y.V., and Stefanyshyn, D.V. (2014). Mathematical modelling the conditions of intensification of the riverbed local erosion behind of obstacle that deviates from the shore downstream. Zeszyty Naukowe Inżynieria Lądowa i Wodna w Kształtowaniu Środowiska, Nr 10, Kalisz, 7-18.

19. Julien, P.Y. (2010). Erosion and sedimentation. Cambridge University Press, 371 p.

20. Fagherazzi, S., Edmonds, D. A., Nardin, W., Leonardi, N., Canestrelli, A., Falcini, F., Jerolmack, D.J., Mariotti, G., Rowland, J.C., and R. L. Slingerland (2015). Dynamics of river mouth deposits. Rev. Geophys., 53, 642-672; doi: https://doi.org/10.1002/2014RG000451.

21. Cao, Z. and Carling, P. A. (2002). Mathematical modelling of alluvial rivers: reality and myth. Part I: General review. Proc. of the Institution of Civil Engineers Water \& Maritime Engineering, 154, Issue 3, 207-219.

22. Two-Dimensional Hydraulic Modeling for Highways in the River Environment. Ref. Document. (2019). Publ. No. FHWA-HIF-19-061, U.S. Department of Transportation, FHWA, 301 p. Available from https://portal.ct.gov/-/media/DOT/documents/ddrainage/2-DHydraulic-Modeling-Reference-Document.pdf.

23. Nikishov, V.I. (2007). From hydraulics of open streams to hydromechanics of river systems. Applied hydromechanics, Vol. 9, No. 2-3, 103-121. (in Russian).

24. The UN-Water Status Report on the Application of Integrated Approaches to Water Resources Management. (2012). Nairobi, Kenya, 119 p. Available from https://www.un.org/waterforlifedecade/pdf/un_water_status_report_2012.pdf.

25. De Wrachien, D., Mambretti, S. and Sole, A. (2010). Mathematical models in flood management: overview and challenges. WIT Transactions on Ecology and the Environment, Vol. 133, 61-72; doi: https://doi.org/10.2495/FRIAR100061.

26. Gül, G.O., Harmancioğlu, N., Ali Güll, A. (2010). A combined hydrologic and hydraulic modelling approach for testing efficiency of structural flood control measures. Nat. Hazards, 54, 245-260; DOI: https://doi.org/10.1007/s11069-009-9464-2. 
27. Kasvi, E., Alho, P., Lotsari, E., Wang, Y., Kukko, A., Hyyppä, H., and Hyyppä, Yu. (2014). Two-dimensional and three-dimensional computational models in hydrodynamic and morphodynamic reconstructions of a river bend: sensitivity and functionality. Hydrological Processes, Pub. online in Wiley Online Library; DOI: https://doi.org/10.1002/hyp.10277.

28. Giustolisi, O. (2004). Using genetic programming to determine Chézy resistance coefficient in corrugated channels. Journal of Hydroinformatics, 06.3, 157-173.

29. Hin, L.S., Bessaih, N., Ling, L.P., Ghani, A.A., Zakaria, N.A., and Seng, M.Y. (2008). A study of hydraulic characteristics for flow in equatorial rivers. International Journal of River Basin Management, 6:3, 213-223.

DOI: https://doi.org/10.1080/15715124.2008.9635349.

30. Machiels, O., Erpicum, S., Archambeau, P., Dewals, B., and Pirotton, M. (2009). Bottom friction formulations for free surface flow modeling, Proc. of the 8th NCTAM Congress, Brussels. Available from http://hdl.handle.net/2268/28208.

31. Dash Saine S., Khatua, K.K., Naik, B., and Mohanty, P.K. (2013). Energy loss for a highly Meandering open Channel Flow. Research J. of Eng. Sciences. Vol. 2 (4), 22-27.

32. Stewart, M.T., Cameron, S. M., Nikora, V. I., Zampiron, A., and Marusic, I. (2019). Hydraulic resistance in open-channel flows over self-affine rough beds. J. of Hydraulic Research, 57:2, 183-196; DOI: https://doi.org/10.1080/00221686.2018.1473296.

33. Zhu, X., Liu, B., and Liu, Y. (2020). New Method for Estimating Roughness Coefficient for Debris Flows. Water, 12, 2341; doi: https://doi.org/10.3390/w12092341.

34. Fenton, J.D. (2010). Calculating resistance to flow in open channels. Alternative Hydraulics Paper 2. Available from http://johndfenton.com/Alternative-Hydraulics.html.

35. Dyakonova, T., and Khoperskov, A. (2018). Bottom friction models for shallow water equations: Manning's roughness coefficient and small-scale bottom heterogeneity. IOP Conf. Series: Journal of Physics: Conf. Series 973.

DOI: https://doi.org/10.1088/1742-6596/973/1/012032.

36. Liang, D., Falconer, R.A., and Lin, B. (2007). Linking one- and two-dimensional models for free surface flows. Water Management, Vol. 160, Issue 3, 145-151; https://doi.org/10.1680/wama.2007.160.3.145.

37. Wang, Yu., Liang, Q., Kesserwani, G., and Hall, J.W. (2011). A 2D shallow flow model for practical dam-break simulations, Journal of Hydraulic Research, 49:3, 307-316; DOI: https://doi.org/10.1080/00221686.2011.566248.

38. De Wrachien, D., Mambretti, S., and Sole, A. (2010). Mathematical models in flood management: overview and challenges. WIT Trans. on Ecology and the Environment, Vol. 133. Flood Recovery, Innovation and Response, 61-72.

DOI: https://doi.org/10.2495/FRIAR100061.

39. Costabile, P., Costanzo, C., Maccione, F., and Mercogliano, P. (2012). Two-dimensional model for overland flow simulations: A case study. Eur. Water 38, 13-23.

40. Lousada, S., Loures, L. (2020). Modelling Torrential Rain Flows in Urban Territories: Floods - Natural Channels (The Case Study of Madeira Island). American Journal of Water Science and Engineering, Vol. 6, No. 1, 17-30.

DOI: https://doi.org/10.11648/j.ajwse.20200601.13.

41. Park, I., Song, Ch.G. (2018). Analysis of two-dimensional flow and pollutant transport induced by tidal currents in the Han River. Journal of Hydroinformatics, 20 (3): 551-563; DOI: https://doi.org/10.2166/hydro.2017.118.

42. Esposti Ongaro, T., Cerminara, M., Charbonnier, S.J. et al. (2020). A framework for validation and benchmarking of pyroclastic current models. Bull. Volcanology, 82, 51; DOI: https://doi.org/10.1007/s00445-020-01388-2.

43. Qin, X., Motley, M., LeVeque, R., Gonzalez, F., and Mueller, K. (2018). A comparison of a two-dimensional depth-averaged flow model and a three-dimensional RANS model for predicting tsunami inundation and fluid forces. Natural Hazards Earth System Sci., 18, 2489 2506; DOI: https://doi.org/10.5194/nhess-18-2489-2018. 
44. HEC-RAS River Analysis System. User's Manual V. 6.0. (2021). US Army Corps of Engineers. Inst. for Water Resources. Hydrologic Eng. Center. Available from https://www. hec.usace.army.mil/software/hec-ras/documentation/HEC-RAS_6.0_Users_Manual.pdf. 45. Churuksaeva, V., Starchenko, A. (2015). Mathematical modeling of a river stream based on a shallow water approach. Procedia Computer Science, 4th Int. Young Scientists Conf. on Computational Science,Vol. 66, 200-209; doi: https://doi.org/10.1016/j.procs.2015.11.024. 46. Stefanyshyn D.V., Korbutiak V.M., Stefanyshyna-Gavryliuk Y.D. (2019). Situational predictive modelling of the flood hazard in the Dniester river valley near the town of Halych. Environmental safety and natural resources, Issue 1 (29), 16-27; DOI: https://doi.org/10.32347/2411-4049.2019.1.16-27.

47. Sellier, M. (2016). Inverse problems in free surface flows: a review. Acta Mechanica, 227, 913-935; https://doi.org/10.1007/s00707-015-1477-1

48. Ivashintsov, D.A., Sokolov, A.S., Shulman, S.G., and Yudelevich, A.M. (2001). Parametric identification of hydraulic structural design models. St. Petersburg, VNIIG B.E. Vedeneeva, 431 p. (in Russian).

49. Lagodnyuk, A.M., Korbutyak, V.M., Stefanyshyn, D.V. (2016). Identification of floodplains roughness coefficient with using remote sensing data to support mathematical modelling of unsteady water movement under floods. Environmental safety and natural resources, Issue 2 (22), 83-94. (in Ukrainian).

50. Radoux, Ju., Chomé Gu., Jacques, D.-Ch., Waldner, F., Bellemans, N., Matton, N., Lamarche, C., d'Andrimont, R., and Defourny, P. (2016). Sentinel-2's Potential for SubPixel Landscape Feature Detection. Rem. sensing, 8, 488; doi: https://doi.org/10.3390/rs8060488.

51. Bacoţiu, C. (2020). The quest for the ideal Darcy-Weisbach friction factor equation from the perspective of a building services engineer. Ovidius University Annals Series: Civil Engineering, Vol. 21, No. 1, 65-73; DOI: https://doi.org/10.2478/ouacsce-2019-0008.

52. Zheleznyakov, G.V. (1981). Throughput ability of channels of canals and rivers. Leningrad, Gidrometeoizdat, $311 \mathrm{p}$.

53. Shterenlicht, D.V. (1984). Hydraulics. Moscow, Energoatomizdat, 640 p.

54. Coon, W.F. (1998). Estimation of roughness coefficients for natural stream channels with vegetated banks. Prepared in cooperation with the New York State Department of Transportation, $133 \mathrm{p}$.

55. Hydraulic calculations of spillway hydraulic structures. (1988). Reference manual. Moscow, Energoatomizdat, 624 p. (in Russian).

56. Baryshnikov, N.B. (2003). Hydraulic resistance of river channels. Tutorial. St. Petersburg, Russian State Hydrometeorological University, 147 p. (in Russian).

57. Baryshnikov, N.B. (2016). Channel flow dynamics. St. Petersburg, Russian State Hydrometeorological University. 342 p. (in Russian).

58. Strupczewski, W.G., Szymkiewicz, R. (1996). Analysis of paradoxes arising from the Chezy formula with constant roughness: I. Depth-discharge curve. Hydrological Sciences Jour., 41:5, 659-673; DOI: https://doi.org/10.1080/02626669609491537.

59. Jiménez-Medina, O. (2015). Fórmulas generales para los coeficientes de Chézy y de Manning. Water Technology and Sciences, 6 (3), 33-38 (in Spanish).

60. Lama, G.F.C., Errico, A., Francalanci, S., Solari, L., Preti, F., and Chirico, G.B. (2020). Evaluation of Flow Resistance Models Based on Field Experiments in a Partly Vegetated Reclamation Channel. Geosciences, 10, 47;

doi: https://doi.org/10.3390/geosciences10020047.

61. Khatua, K.K., Patra, K.C., and Nayak, P. (2011). Meandering effect for evaluation of roughness coefficients in open channel flow. River Basin Management VI. WIT Trans. on Ecology and the Environment, Vol. 146, 213-224; doi: https://doi.org/10.2495/RM110191. 62. Zidan, A. R. A. (2015). A review of friction formulae in open channel flow. International Water Technology Journal, Vol. 5, No. 1, 43-57. 
63. Wang, W.-J., Peng, W.-Q., Huai, W.-X., Katul, G.G., Liu, X.-B., Qu, X.-D., and Dong, F.(2019). Friction factor for turbulent open channel flow covered by vegetation. Scientific reports. 9:5178; doi: https://doi.org/10.1038/s41598-019-41477-7.

64. Zeghadnia, L., Robert, J. L., and Achour, B. (2019). Explicit solutions for turbulent flow friction factor: A review, assessment and approaches classification. Ain Shams Engineering Jour., 10, 243-252; doi: https://doi.org/10.1016/j.asej.2018.10.007.

65. Arcement, G.J., and Schneider, V.R. (1989). Guide for Selecting Manning's Roughness Coefficients for Natural Channels and Flood Plains. United States Geological Survey, Watersupply Paper 2339; doi: https://doi.org/10.3133/wsp2339

66. Kim, Ji-S., Lee, Ch.-J., Kim, W., and Kim, Y.-J. (2010). Roughness coefficient and its uncertainty in gravel-bed river. Water Science and Engineering, Vol. 3, No. 2, 217-232; doi: https://doi.org/10.3882/j.issn.1674-2370.2010.02.010.

67. Al-Asadi, K., and Duan, J.G. (2017). Assessing methods for estimating roughness coefficient in a vegetated marsh area using Delft3D. Journal of Hydroinformatics, 19(5), 766-783; DOI: https://doi.org/10.2166/hydro.2017.064.

68. Ye, A., Zhou, Zh., You, J., Ma, F., and Duan, Q. (2018). Dynamic Manning's roughness coefficients for hydrological modelling in basins. Hydrology Research, 49. 1379-1395; DOI: https://doi.org/10.2166/nh.2018.175.

69. Sadeh, Y., Cohen, H., Maman, S., and Blumberg, D.G. (2018). Evaluation of Manning's $n$ Roughness Coefficient in Arid Environments by Using SAR Backscatter. Remote Sensing, 10, 1505; doi: https://doi.org/10.3390/rs10101505.

70. Mamedov, A. Sh. (2011). On the calculation of the Chezy coefficient of the river flow. Hydraulics, hydrology, water resources, 3, 62-67. (in Russian).

71. Achour, B. (2015). Chezy's Resistance Coefficient in a Rectangular Channel. Journal of Scientific Research \& Reports, 7(5), 338-347.

72.Karim, L., and Larue, J.-P. (2016). Évaluation du Coefficient De Frottement Dans Le Cas D’un Écoulement À Surface Libre. European Scientific Journal, Vol.12, No.15, 418-433; doi: https://doi.org/10.19044/esj.2016.v12n15p418. (in French).

73. Lepikhin, A.P., Bogomolov, A.V., Dalkov, M.P. (2012). Estimation of the Chezi coefficient: tradition and state of the art. Water management of Russia, No. 3, 57-77. (in Russian).

74. Karasev, I.F. (2007). Hydraulic resistance and system morphometry of self-forming riverbeds and canals. Bulletin of the Russian State Pedagogical University, No. 7 (26), 153-164. (in Russian).

75. Limerinos, J. (1970). Determination of the Manning Coefficient From Measured Bed Roughness in Natural Channels. Studies of flow in alluvial channels. US Government printing office, Washington, $51 \mathrm{p}$.

76. Altshul, A.D., U-Van Thein. (1973). Comparison of formulas without roughness coefficient for determining the average water flow velocity in rivers. Hydrotechnical construction, No 1, 41-42. (in Russian).

77. Volynov, M.A. (2011). The carrying capacity of self-regulating river channels. Environmental management, No 5, 66-70. (in Russian).

78. Grishanin, K.V. (1979). The dynamics of channel flows. Leningrad, Gidrometeoizdat, 312 p. (in Russian).

79. Loukam, I., Achour, B., Djemili, L. (2018). Chezy's resistance coefficient in an eggshaped conduit. Journal of Water and Land Development, No. 37, 87-96; DOI: https://doi.org/10.2478/jwld-2018-0028.

90. Borsuk, O.N. (1960). Influence of waves and water level pulsations on mountain rivers on the accuracy of water-measuring observations. Proc. of the State Hydrological Institute, Issue 90. (in Russian).

The article was received 17.05.2021 and was accepted after revision 26.08.2021 


\section{Д.В. Стефанишин, Я.В. Ходневич, В.М. Корбутяк}

\section{ОЦНКА КОЕФЦЦЕНТА ШОРСТКОСТІ ШЕЗІ ЯК ХАРАКТЕРИСТИКИ ГІДРАВЛІЧНОГО ОПОРУ ПОТОКУ В РІЧКОВИХ РУСЛАХ: ЗАГАЛЬНИЙ ОГЛЯД, ІСНУЮЧІ ПРОБЛЕМИ ТА ШЛЯХИ ЇХ ПОДОЛАННЯ}

Анотація. У роботі подано систематизований огляд проблеми розрахунку коефіцієнта шорсткості Шезі як однієї з емпіричних характеристик гідравлічного опору, яка найбільш часто використовується на практиці. Огляд подається в контексті формування достовірних емпіричних даних, необхідних для підтримки гідротехнічних розрахунків та математичного моделювання відкритих потоків у руслах річок. Актуальність проблеми обумовлена великою кількістю практичних завдань, які потребують такого попереднього дослідження. У багатьох випадках точність визначення емпіричних характеристик гідравлічного опору може значною мірою вплинути на точність вирішення завдань річкової гідравліки, що стосуються проектування гідротехнічних споруд та управління водними ресурсами річок, незалежно від обраних математичних моделей або методів.

Річки характеризуються значним різноманіттям умов течії, тому гідравлічний опір потокам у річках може змінюватися в широких межах, визначаючи пропускну здатність русел. Якщо взяти до уваги різноманітність гідроморфології та гідрології річок, коефіцієнт шорсткості Шезі видається найбільш повною характеристикою гідравлічного опору відкритим потокам у річкових руслах порівняно 3 іншими інтегральними емпіричними характеристиками гідравлічного опору.

В даний час існує велика кількість емпіричних і напівемпіричних формул для розрахунку коефіцієнта шорсткості Шезі. Основною метою цього дослідження було проаналізувати та систематизувати їх у контексті забезпечення належної підтримки завдань річкової гідравліки, зокрема математичного моделювання відкритих потоків в річках. Для досягнення мети дослідження було проведено огляд літератури щодо проблеми визначення інтегральних характеристик гідравлічного опору відкритій течії в річкових руслах, а також досліджено та систематизовано найбільш відомі формули, які використовуються для розрахунку коефіцієнта шорсткості Шезі на практиці. Загалом було проаналізовано та систематизовано 43 формули для розрахунку коефіцієнта шорсткості Шезі, а також 13 формул, які можна використовувати для оцінки коефіцієнта шорсткості Маннінга. На основі всіх цих формул можна скласти близько 250 емпіричних рівнянь для розрахунку коефіцієнта Шезі залежно від гідроморфологічних особливостей річок та річкових русел, гідравлічних умов, меж застосування формул тощо.

Ключові слова: емпіричні характеристики; гідравлічний опір; відкриті потоки; річкова гідравліка; річкові русла; коефіцієнт шорсткості Шезі

Стаття надійшла до редакиії 17.05.2021 і прийнята до друку після рещензування 26.08.2021

\section{Стефанишин Дмитро Володимирович}

доктор технічних наук, провідний науковий співробітник Інституту телекомунікацій і глобального інформаційного простору НАНУ

Адреса робоча: 03186 Україна, м. Київ, Чоколівський бульвар, 13

ORCID: https://orcid.org/0000-0002-7620-1613 e-mail: d.v.stefanyshyn@gmail.com

\section{Ходневич Ярослав Васильович}

кандидат технічних наук, науковий співробітник Інституту телекомунікацій i глобального інформаційного простору НАНУ

Адреса робоча: 03186 Україна, м. Київ, Чоколівський бульвар, 13

ORCID: https://orcid.org/0000-0002-5510-1154 e-mail: ya.v.khodnevych@ gmail.com 


\section{Корбутяк Василь Михайлович}

кандидат технічних наук, доцент кафедри землеустрою, кадастру, моніторингу земель та геоінформатики Національного університету водного господарства та природокористування

Адреса робоча: 33028 Україна, м. Рівне, вул. Соборна, 11

ORCID: https://orcid.org/0000-0002-8273-2306 e-mail:v.m.korbutiak@nuwm.edu.ua 